\title{
The Impact of the Sharing Economy as an Ecosystem on the Tourism Sector
}

\author{
Valentinas Navickas \\ School of Economics and Business, Kaunas University of Technology, Lithuania \\ Ieva Petrokè \\ School of Economics and Business. Kaunas University of Technology, Lithuania \\ Vaida Bačiulienè \\ School of Economics and Business. Kaunas University of Technology, Lithuania \\ Tetiana Vasylieva \\ Institute of Business, Economics and Management. Sumy State University, Ukraine
}

Received: 10 February 2021. Revision received: 15 March 2021. Accepted: 25 March 2021

\begin{abstract}
The authors of the article investigated the sharing economy elements as an ecosystem and analyzed the advantages and disadvantages of the sharing economy in the tourism sector. Exploring the elements of the sharing economy's ecosystem can help identify the challenges of globalization and lead to exploiting the sharing economy's potential more efficiently in the tourism sector. The study of the impact of the sharing economy as an ecosystem on the tourism sector is also made relevant by the lack of research examining the advantages and disadvantages of sharing economy models. To determine the impact of the sharing economy on the tourism sector, the authors analyzed the scientific literature. An empirical study of business models based on the sharing economy in the tourism sector was carried out. Moreover, the advantages and disadvantages were identified of the sharing economy in the tourism sector. The authors' analysis has shown that, despite conflicting views on the impact and importance of the sharing economy in the tourism sector, many experts are optimistic about sharing economy-based models in this sector. Research by the authors of the article shows that sharing economy-based businesses are superior to traditional business models. The sharing economy-based models are preeminent because of more affordable prices for tourists, better satisfaction of individual needs, opportunities to become part of the community, a more comprehensive range of services, better access to tourism services. A better quality of services also highlights the advantages of economy-based businesses. Although the study was conducted in the Lithuanian tourism sector, we can assume that the study data can be unified and applied to analyze similar markets in other countries.
\end{abstract}

Key Words: sharing economy, sharing economy models, ecosystem, tourism sector.

JEL Classification: L8, L83, L84.

Reference: Navickas V., Petrokè, I., Bačiulienè, V. \& Vasylieva, T. (2021). The Impact of the Sharing Economy as an Ecosystem on the Tourism Sector. Journal of Tourism and Services, 22 (12), 66-88. doi: 10.29036/jots.v12i22.241

\section{Introduction}

With the processes of globalization and the integration of the world's economy, the importance of information technology in global economic relations is growing. Changes in societal values, financial capacity, and technological advances in online platforms drive the sharing economy's growth by involving interconnected online users who distribute and use unexploited resources. The United Nations World Tourism Organization (2016) and the Committee of the Regions (2017) point out that the tourism sector 


\section{JOURNAL OF TOURISM AND SERVICES}

Issue 12, volume 22, ISSN 1804-5650 (Online)

www.jots.cz

needs to be given high priority due to the tourism sector's sharing practices prevalence. According to the World Travel and Tourism Council (WTTC, 2019) the economic contribution of the sharing economy to the tourism sector was $10.3 \%$ gross domestic product [GDP] worldwide. The sharing economy has become one of the largest and fastest-growing markets in the world. According to the European Commission (2017), in 2015, total revenue from cooperation platforms and service providers in the European Union amounted to $€ 28$ billion. It is stated that in 2025 transactions on sharing economy platforms could amount to $€ 570$ billion. The development of the sharing economy in the tourism sector has contributed to economic growth. However, it has also sparked protests in which traditional businesses and supporters have fought against the sharing economy's market-based models. It is noticeable that governments, communities, competitors have different attitudes and assessments of the sharing economy-based models. According to that, it is essential not only to analyse the impact of the sharing economy by highlighting its strengths and weaknesses but also to identify and characterize the sharing economy's key elements as an ecosystem.

The research problem. During the analysis of the scientific literature, it is noted that only a few studies have been designed to analyse the impact of the sharing economy in the tourism sector so far (Ferrer, 2018; Hong, 2018; Ključnikov et al., 2017; Krajcik et al., 2019), despite the popularity of the sharing economy and researches in other sectors, e.g., finance, transport, accommodation services (Bosque, 2018; Chen and Kockelman, 2016; Srovnalikova, Semionovaitè, Baranskaite and Labanauskaité, 2020; Ključnikov, Krajčik, Vincurova, 2018). Several authors also paid great attention to the legal perspective of the sharing economy and the challenges brought by the sharing economy itself (Onete, Plesea and Budz, 2018; Balionyté, 2017; Schwab, 2018; Schor, 2016; Mair and Reischauer, 2017; Lombard, 2015; Martucci, 2018; Lougher and Kalmanowicz, 2016). Many authors who have studied the sharing economy emphasize that the sharing economy is a complex, pervasive business model that changes consumers' perceptions of business, expectations and affects many areas of the economy. There is a lack of information on the functioning, stakeholders and impact of the sharing economy-based models. Thus, with the growing potential of sharing economy-based models in the tourism sector and the lack of scientific literature and research, there is a need to research sharing economy-based models. In this study, it is attempted to determine the positive and negative economic, socio-cultural and environmental effects of sharing economy as an ecosystem.

The research aim - to determine the impact of the sharing economy on the tourism sector.

The goals of the research:

1. to analyse the concept of sharing-economy-based business models ecosystem;

2. to determine the influence of sharing economy for the tourism sector;

3. to evaluate the sharing-economy-based business models in Lithuanian tourism sector.

\section{Research methods:}

1. systematic and comparative analysis of scientific literature;

2. expert evaluation;

3. methods of descriptive statistics.

\section{Literature review. Theoretical background.}

The origins of the sharing economy go back to ancient Roman times when the wealthiest allowed the public to use the wellness facilities in private villas for a set fee. The emergence of the modern sharing economy is associated with North American, Asian and Australian countries with high urbanization levels, the majority of the millennials (born between 1981 and 1996), and the extreme popularity of 


\section{JOURNAL OF TOURISM AND SERVICES}

Issue 12, volume 22, ISSN 1804-5650 (Online)

www.jots.cz

smartphones. With the growing popularity of the sharing economy in the tourism sector, the concept of "sharing economy" has caused debate among scientists (Gerve and Silva, 2020; Teubner and Flath, 2019).

Although many authors have analysed the sharing economy, the sharing economy's definition is still at the centre of scientific discourse. However, most authors point out that the sharing economy involves human interaction. In defining the concept of a sharing economy, many scholars also indicate that transactions can be monetary and non-monetary (Bostman and Rogers, 2010; Mair and Reischauer, 2017; Frenken and Schors 2017; Uddin et al., 2021). Most authors focus on new ways of allocating resources that create value. However, there is disagreement about what type of capital (human or only physically tangible) can be included in the concept of the sharing economy's object. Some authors point out that sharing can only include physical, underused assets (Frenken and Schor, 2017; Bostman and Rogers, 2010).

Analysing the definitions of the sharing economy by different authors, we notice no consensus on which areas or platforms belong to the sharing economy. However, distinguishing the sharing economy's main features, we can say that the sharing economy in the tourism sector can be defined as sharing knowledge (including ideas, experiences, information transfer), sharing tourism services, sharing objects, and other tourism activities.

\subsection{The Characteristics and Dimensions of the Sharing economy as an ecosystem}

The sharing economy in the tourism sector can be analysed as an ecosystem, as it involves several interrelated interest groups that co-exist and interact in a dynamic environment (Leung, Xue \& Han, 2019). Ecosystems are seen as open communities consisting of service providers, consumers, platforms, partners, public authorities, competitors and the community (Parente, Geleilate \& Rong, 2018; Popesko et al., 2016). The picture below (Figure 1.) shows that the sharing economy's ecosystem is illustrated, consisting of two interrelated layers.

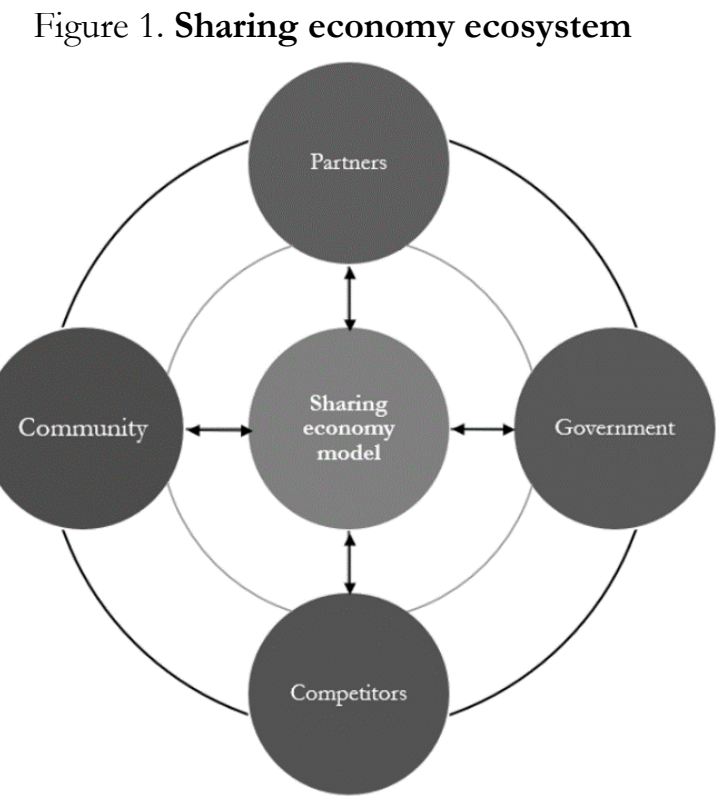

Source: Authors own conception

The first layer of the sharing economy ecosystem consists of the platforms, service providers and tourists (consumers), whose activities and interactions are the main products of the sharing economy in the tourism sector. 


\section{JOURNAL OF TOURISM AND SERVICES}

Issue 12, volume 22, ISSN 1804-5650 (Online)

www.jots.cz

Its second layer consists of partners, competitors, public authorities and local communities which are connected together. The businesses which are based on the sharing economy and all stakeholders interact and shape each other. The layers of the sharing economy ecosystem in the tourism sector are analysed separately below.

The first layer of the ecosystems is illustrated in detail in Figure 2. Within the framework of the sharing economy's traditional triangulation model, the main issues related to the sharing economy and business processes are examined.

Figure 2. Key elements of the sharing economy model

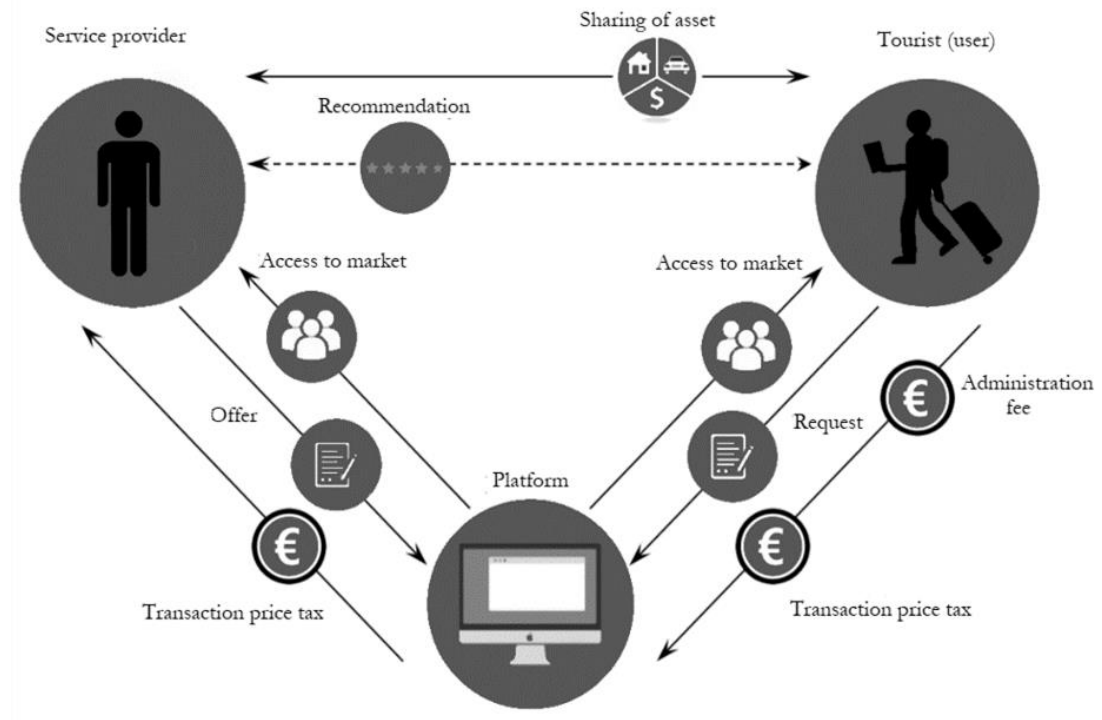

Source: Authors own conception on the basis of Šiuškaitė et al., 2019

Although the bilateral relationship is often seen in traditional markets, the tourism sector's sharing economy is characterized by three-way transactions. In the sharing economy service triangle, sharing economy platforms are intermediaries connecting customers who need services (tourists) with service providers. Many of the services offered by sharing economy platforms in the tourism sector are seen as alternatives to traditional accommodation, leisure and transportation services. Consumers and services providers operating on sharing economy platforms create new tourism experiences, transforming values, motives, reasons, and traveling methods.

The platform's primary function is to mediate and develop social interactions and economic transactions between service providers and tourists. According to the presented model (Figure 2), service providers publish information about the tourism product on the platforms. The online trading platform provides access to the market and information to tourists (Bilan et al., 2019). Platforms are based on mutual trust between market participants. Therefore, often exercise control over the perception of reputation and value (Curtis \& Lehner, 2019; Pjerotic, 2017). According to Ivanova (2015), the provided service's mediation and quality assurance are essential to implement tourists' expectations.

In summary, we can say that the sharing economy's business models reveal the change that occurs when digital resources and various combinations of digital platforms are used to maintain a different relationship with material resources (Bilan et al., 2019).

The second layer of the sharing economy ecosystem is further analysed (Figure 1).

Competitors. The main competitors of the sharing economy in the tourism sector are often companies based on the sharing economy and traditional businesses. It is observed that competition between sharing economy platforms in the tourism sector is not significant. According to research at Kansai University in Japan (World Bank Group, 2018), the more users are attracted to sharing economy 


\section{JOURNAL OF TOURISM AND SERVICES}

Issue 12, volume 22, ISSN 1804-5650 (Online)

www.jots.cz

platforms, the better algorithms become and more platforms can generate revenue, invest in data management, and become more efficient business organizations. Parente et al. (2017) affirm that sharing economy platforms in the tourism sector is affected by the network effect, which increases as more users use the platforms and expand the network so that competition between incumbents and new sharing economy-based platforms is relatively low and inflexible.

However, a much more complicated situation in the tourism sector is observed between sharing economy-based and traditional businesses. A comparative analysis of the sharing economy's operation principles and traditional business models in the tourism sector is carried out (Figure 3).

Figure 3. Traditional business model

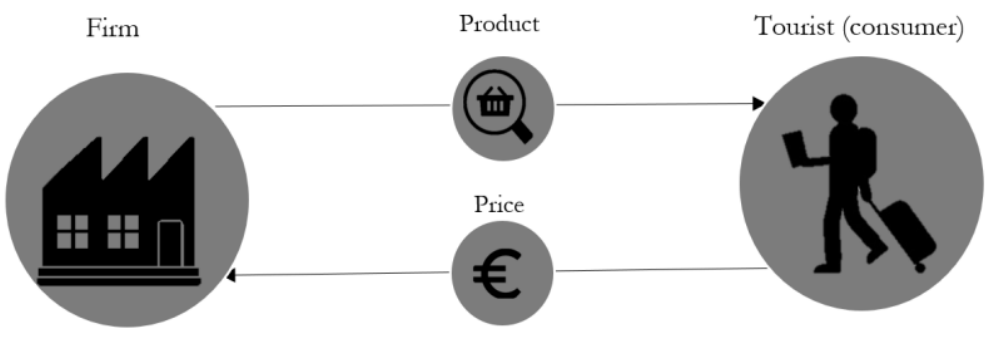

Source: Authors own conception

In contrast to the sharing economy, which focuses on virtual markets, connects service providers and tourists according to their different needs, traditional business in the tourism sector focuses on the business development and commercialization of unified products or services (Parente et al., 2017). Unlike in the sharing economy model, the economy's traditional business model is static, with no redistribution of roles (the service user cannot be either the service provider or vice versa) (Figure 3).

Companies in the sharing economy also differ from traditional companies in the tourism sector regarding management processes, value proposition, and revenue generation (Table 1).

The provided value can be assessed for sharing economy users in terms of ease to use, response speed, variety of choices (tourism objects, destinations, features of tourism services), the ability to offer a unique, niche tourism service according to customer needs.

Table 1. Differences between the sharing economy and traditional business

\begin{tabular}{|c|c|c|}
\hline & Traditional business: & Sharing economy: \\
\hline $\begin{array}{l}\text { Service value } \\
\text { proposition }\end{array}$ & $\begin{array}{l}\text { - } \text { quality and reliability; } \\
\text { - property; } \\
\text { - additional services. }\end{array}$ & $\begin{array}{l}\text { - } \quad \text { wide choice, unique products and services; } \\
\text { - } \quad \text { new experience; } \\
\text { - } \quad \text { flexibility (according to need); } \\
\text { - } \quad \text { speed; } \\
\text { - } \quad \text { convenience (fast service, easy to use). }\end{array}$ \\
\hline $\begin{array}{l}\text { Management } \\
\text { process }\end{array}$ & $\begin{array}{l}\text { - } \text { acquisition and } \\
\text { production of } \\
\text { products; } \\
\text { - inventory } \\
\text { maintenance; } \\
\text { - client consultation. }\end{array}$ & $\begin{array}{l}\text { - } \quad \text { consumers as service providers; } \\
\text { - } \quad \text { alternative trust mechanism (feedback, rating); } \\
\text { - help for consumers; } \\
\text { - data management. }\end{array}$ \\
\hline Revenue & - profit margin. & - $\quad$ commissions. \\
\hline
\end{tabular}




\section{JOURNAL OF TOURISM AND SERVICES}

Issue 12, volume 22, ISSN 1804-5650 (Online)

www.jots.cz

Sharing economy-based companies in the tourism sector manage relationships with customers through a digital platform where formal and informal rules govern the relationship between competitors, providers and tourists. Traditional companies in the tourism sector usually rely on a clear structure that defines tourism service provision standards. Traditional companies also regulate the service provider's responsibilities and obligations, ensuring that the tourism service meets required quality standards, defines responsibilities and risks related to providing tourism services. Traditional businesses in the tourism sector also provide access to additional services.

One of the main differences is the number of costs required to carry out the services. Traditional companies must acquire all the necessary inventory for certain activities, employ people, and acquire other essential equipment and tools (Ključnikov et al., 2019). The initial costs of sharing economy-based businesses operating in the tourism sector are fixed, related to the digital platform's development, and variable expenses related to its maintenance. Companies in the sharing economy do not manage the tangible assets directly related to the goods offered. However, sharing economy-based companies have relatively high investments in the maintenance and development of the information platform infrastructure. Sharing economy companies generate revenue streams by receiving commissions on each transaction executed. Transactions in the tourism sector's sharing economy are also characterized by various compensation forms for the services provided (exchanges, trade, gifts). In a traditional economy, the main form of compensation is cash payments to receive a good or service. Thus, depending on the costs incurred, shared-economy companies in the tourism sector can offer a lower price.

Partners. Typical partners of sharing economy companies in the tourism sector are payment system companies, credit card companies, insurance companies and companies providing rating services. Yang, Ma, and Zhang (2018) pointed out that comments and rankings in a reputation rating system significantly impact community trust and willingness to purchase the service. When choosing services, tourists conclude the reliability of the proposed tourism product by analysing the information provided by other community members. The better rating of the tourism service provider is, the more consumers tend to choose the service provider or the service. Companies in the sharing economy do not create or provide the service themselves, so the quality of the provided service and value designed for tourists directly depends on the service providers. Thus, reliable partners are only one of the key elements in developing a sharing economy in the tourism sector.

Government. The governance element in the sharing economy tourism sector's ecosystem includes government, organizations, laws and regulations.

The rapid development of the sharing economy has led many tourist destinations to take regulatory and restrictive measures. According to Frenken (2016), the evaluation of sharing platforms takes place in reverse order. Usually, before new products are placed on the market, a thorough scientific analysis, deliberations and regulatory agreements are carried out. On the contrary, sharing economy platforms have entered the tourism market without consultation and encourage governments to take impulsive action due to rapid growth. The typical response of regulators to the development of sharing economy platforms has been to create boundaries between the sharing economy and the traditional economy by setting a cap on the sharing economy's activities.

According to the Lithuanian Competition Council (2016), businesses based on the sharing economy must be regulated, but only to the extent that consumer rights are guaranteed. It is argued that the regulation of services in the sharing economy should not build on existing requirements for traditional services and should lead to the updating of current conditions for business, which should be adapted to market developments. Some authorities argue that the sharing economy activities should not be restricted by law but should be subject to market self-regulation.

The taxation of business in the sharing economy is also a significant concern for the authorities, which has not been treated unequivocally. The sharing economy business has been accused of not 


\section{JOURNAL OF TOURISM AND SERVICES}

Issue 12, volume 22, ISSN 1804-5650 (Online)

www.jots.cz

collecting identical taxes as a traditional business, and the issue of personal tax treatment has also sparked much debate (Leung, Xue, and Wen, 2018).

There are also fear that sharing economy platforms in the tourism sector could grow into a monopoly, as it has happened with search and social media platforms.

In addition to online service providers and consumer society, communities that feel the direct impact of sharing economy-based models in the physical place are also important. According to Vaskelainen and Piscicelli (2018), communities are often characterized by emotional intimacy, making it difficult for businesses such as the sharing economy to penetrate and develop in the market. It is illustrated by trade union protests in countries such as Greece, which have led to increased business development restrictions based on the sharing economy.

\subsection{The dualistic impact of sharing economy models in the tourism sector}

The growth of the sharing economy has transformed service delivery models that have a dual impact on existing businesses, regulators and the workforce as a whole.

\subsubsection{Positive effects on sharing economy models in the tourism sector}

The positive effects on the sharing economy in the tourism sector are revealed through the economic, environmental and social impacts (Figure 4).

Figure 4. Positive effects of the application of sharing economy models in the tourism sector

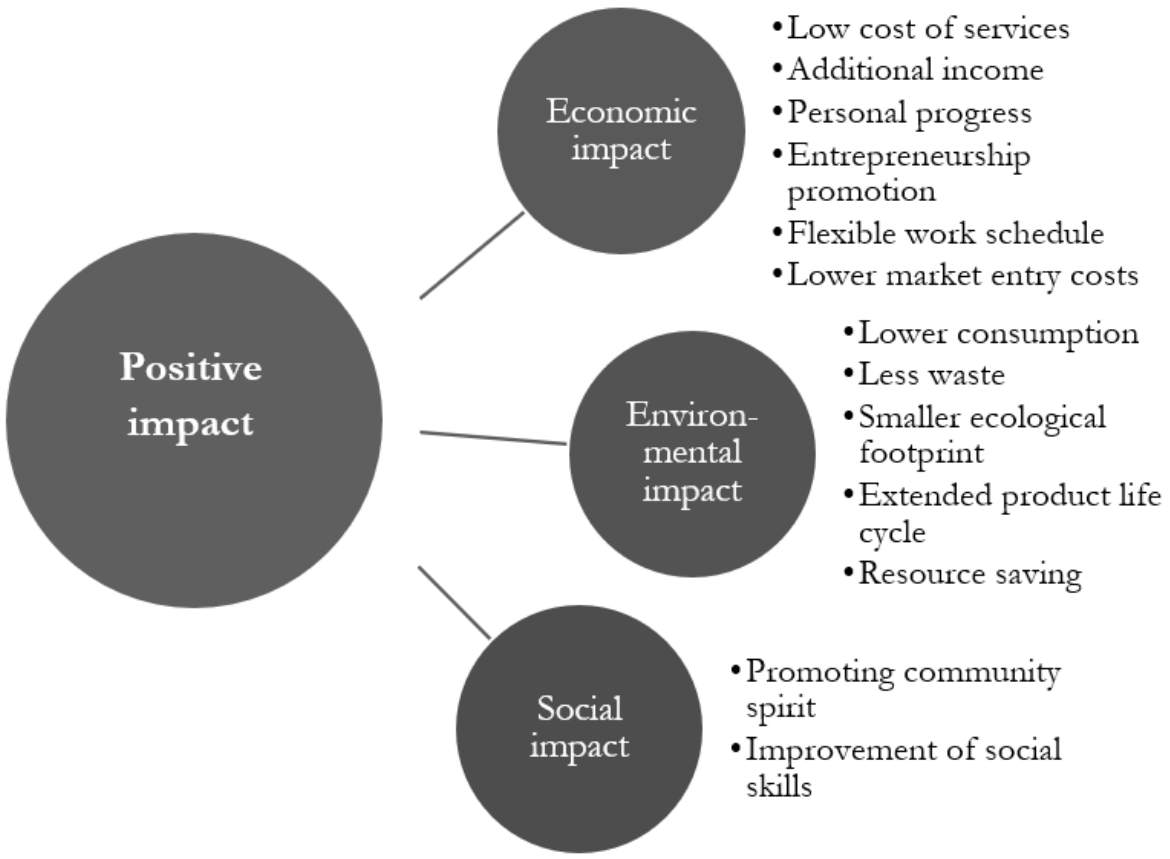

Source: Authors own conception

Economic impact. Digital platforms make it easier and cheaper for people to offer accommodation and other services in the global market. The growing interest in non-tourist destinations has also allowed the local community members to earn additional income by fulfilling the tourists' demand for short-term accommodation and other needs. Yang et al. (2018), Šiuškaitè et al. (2019) points out that consumers in the sharing economy also get economic benefits such as a wider choice of goods and services, personal progress, the promotion of entrepreneurship, flexible and individually personalized 


\section{JOURNAL OF TOURISM AND SERVICES}

Issue 12, volume 22, ISSN 1804-5650 (Online)

www.jots.cz

work schedules. Digital platforms have made it possible to expand small personal transactions to mass exchanges between strangers, reducing the cost of entry and transactions for individual service providers. Sharing economy-based platforms allow tourists to easily compare prices from different providers, get more information about the products or services, view other users' opinions, and communicate directly with the product or service provider.

The advantages of developing the sharing economy in the environment are lower consumption and waste, saving of resources and lower ecological footprint (Dkhili, 2018). In recent years, cultural and economic changes have led tourists to be more open to the idea of sharing resources and using goods temporarily rather than purchasing or storing them. There is also seen a growing concern about the needs of future generations (Ibragimov et al., 2019). Yang et al. (2018) investigated that the sharing economy's environmental benefits are focused on resource sharing and extended product life cycle. A study by the University of New York found that developing a sharing economy by attracting visitors to less known locations helps reduce the flow of tourists and visitors to high-intensity tourist destinations (The World Bank Group, 2018). According to Frenken and Schor (2017), sharing in the tourism sector is a positive phenomenon as it reduces the construction of new facilities (in the case of hotels or common areas).

The social benefits of a sharing economy are promoting community spirit, enhancing social and communication skills, and the opportunity to increase social inclusion and mobility. The popularity of sharing economy businesses in the tourism sector allowed tourists to visit and get to know remote, nontourist communities with visitor-friendly infrastructure (restaurants, entertainment centres, hotels) to build a personal relationship. It is noticeable that by organizing individual experiences or providing other services tailored to tourists, the experiences become individual. Unlike official guided tours following a pre-planned route, small tours organized by locals allow the locals to interact with the locals regularly or even change the excursion' route by turning onto a narrow street that interests the travellers or extending the tour to the dinner table.

\subsubsection{Negative effects of sharing economy - based models in the tourism sector}

Most authors who have studied the sharing economy pay close attention to the sharing economy's efficiency and benefits. However, some authors emphasize that the development of business models in the sharing economy has revealed consequences of concern to the tourism sector, negatively impacting it (Figure 5).

Negative legal effects. The negative impact has accrued due to workers' rights because of unclear employee responsibilities, transparency and low wages. Digital technologies and the global communications infrastructure have changed the traditional perception of work and pay. Although the new type of work provides an opportunity to work with a more flexible work schedule and may impact the new wave of innovation in the labour market (Domi et al., 2019) uncertainty is observed due to insufficient protection (Schwab, 2018). It is noted that those working in sharing economy-based platforms are not considered as employees of the company and therefore are not guaranteed minimum wage requirements. Yang et al. (2018) points out that while those working through sharing economy platforms in the tourism sector are free to choose their workload and schedule, service providers must also bear the risk of business failure, injury and other disasters. Although the platforms collect commissions, there are no guarantees given to employees. According to Yang (2018), labour relations based on a sharing economy can be considered an exploitation of workers.

It is observed that the late application of laws and regulations has the effect of distorting the level playing field and not ensuring adequate protection for sharing service providers and tourists (Yang et al., 2018). Frenken and Schor (2017) note that improper regulation of the sharing economy can lead to the disappearance of traditional and sharing economy-based markets, leading to the spread of unfair competition. 


\section{JOURNAL OF TOURISM AND SERVICES}

Issue 12, volume 22, ISSN 1804-5650 (Online)

www.jots.cz

Figure 5. Negative effects of sharing economy models in the tourism sector

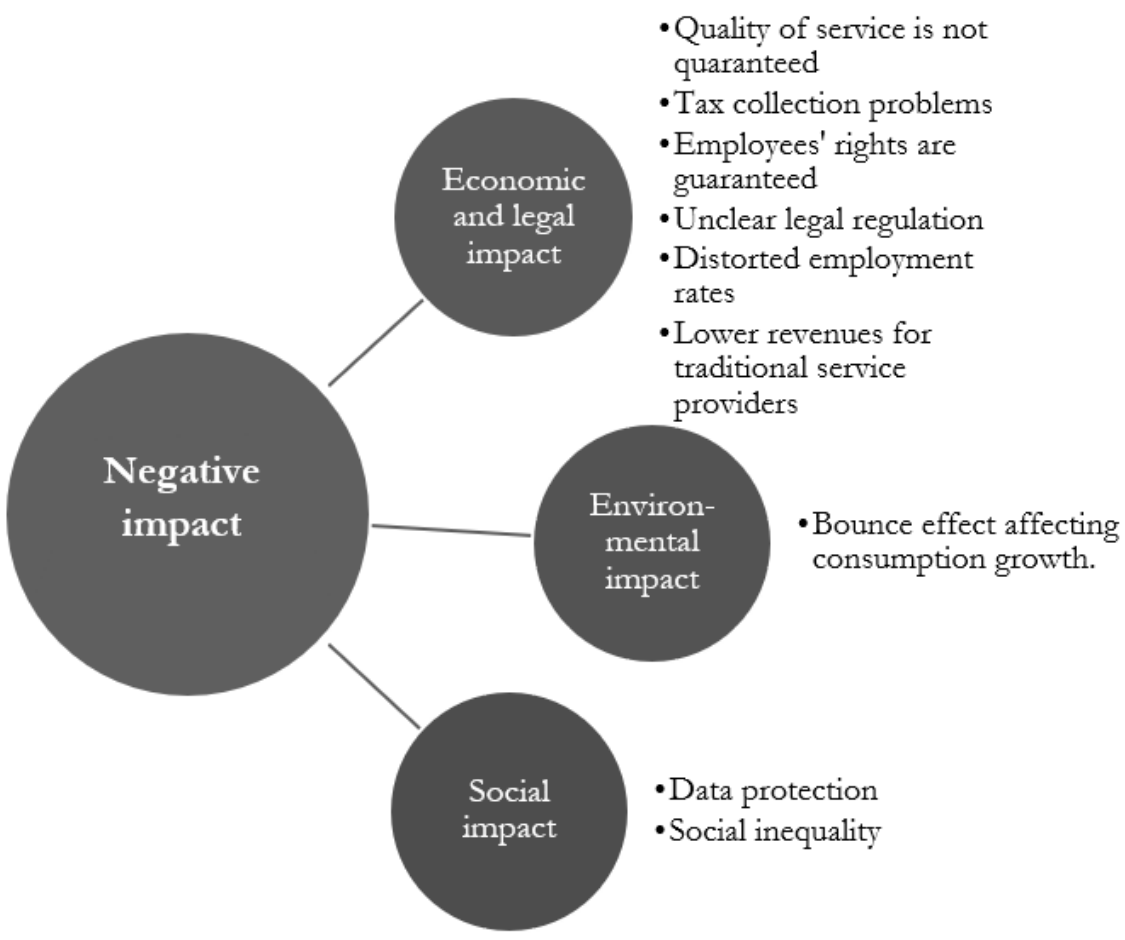

Source: Authors own conception

Lombard (2015), who analysed the sharing economy's problems, notes that the online purchase of services or products through platforms based on the sharing economy does not guarantee quality. There is also a chance that the customer will be deceived, and the product's quality of service will be lower than indicated. With the growing importance of information technology and new models, it is also noticeable that, although detailed rules placed in Europe for collecting, processing, and transmitting personal data, large internet operators receive more information than consumers agree to provide (Vasilieva et al., 2017). Thus, user profiling through big data analysis and inferences paves the way for new, personalized services that can benefit consumers and raise consumer privacy and personal data protection issues.

Negative economic effects. According to Vall and Schor (2020), as the number of service providers operating through sharing economy-based platforms in the tourism sector grows, even during periods of low unemployment, the development of a sharing economy may weaken the standard employment rate, deteriorating overall employment quality. According to Schwab (2018), labour relations based on the sharing economy can also be associated with tax collection problems. It is emphasized that it is more convenient and more attractive for temporary workers to work in the black market. Although payment systems today ensure the transparency of transactions, new decentralized payment systems on the market reduce the purpose for public authorities and private parties to trace the origin of payment transactions. According to Frenken and Shor (2017), sharing economies indirectly affect declining performance indicators in traditional markets. Research has shown (Zervas, 2016, cit. From Frenken and Schor, 2017) that lower-class hotels, which do not meet business customers' needs, suffer the most from the sharing economy's dent. There may also be adverse effects on housing supply and price. 


\section{JOURNAL OF TOURISM AND SERVICES}

Issue 12, volume 22, ISSN 1804-5650 (Online)

www.jots.cz

Negative environmental effects. As the choice of services increases and grows, consumption growth is possible, described as a rebound effect. Vendors sell, rent, or lend to consumers services and goods that are generally lower in price than in the traditional market, so offering a more affordable price to tourists can lead to an undesirable change in consumption, such as additional tourism, longer trip time (Tussyadiah and Pesonen, 2015). From 2013 by 2017, with a 16-fold increase in the number of homes rented through sharing economy platforms in Paris, Paris lost more than 10 percent of the permanent population. As a consequence, school classes decreased, the number of cafes and restaurants increased.

Consoy (2018) also notes the negative social impact of the sharing economy. The reputation of customer-generated ratings caused algorithmic discrimination based on gender, ethnicity and race. A study by Chakraborty, Hannak, Biega, and Gummadi (2017) showed that women and non-white workers receive less positive feedback, lower ratings, lower algorithmic priority causing whose service providers declining earnings and employability. An Airbnb analysis in the United States found out that black men earn about 12 percent less for the same house type in the same location than other landlords (Frenken and Schor, 2017). Discrimination is also observed in other platforms in the tourism economy of the sharing economy.

Frenken and Schor (2017) point out that sharing economy platforms can undermine social cohesion. Although it has been assumed in the past that family members and friends were generally able to use the unused property or goods for free, the opportunity provided to make money through sharing economic platforms may lead to a reduction in altruistic sharing.

\section{Methods}

Research instrument. The instrument chosen for the research is an expert survey. The questionnaire consists of two parts, with a total of 9 questions. The first part of the questionnaire aims to determine the respondents' demographic characteristics - gender, education, the area of the tourism sector represented, and work experience. The second part of the expert survey presents questions aimed at identifying the sharing economy-based businesses that have the most significant impact on the tourism sector, assesses the impact of the sharing economy on traditional businesses, and develops the sharing economy and competitive advantage. The prepared expert survey questionnaire is presented in Annex 1.

Investigation progress. Depending on the research aim, experts from the tourism sector working in various fields of the tourism industry (accommodation, organization of tourism services, etc.) were chosen.

According to Augustinaitis (2009), during the research, to ensure accuracy and reliability, it is recommended to include at least five independent experts, and the minimum recommended size of the expert group is three experts. According to many researchers, the optimal group size of respondents is from eight to ten experts. Eight respondents participated in the expert study, so this number corresponds to the expert group's optimal size and is suitable for further data analysis.

To ensure the reliability and suitability of the obtained data for further analysis, the following requirements were set for the respondents: at least three years of work experience in the tourism sector, education - higher. The concordance coefficient was calculated to assess the compatibility of the group of experts according to the methodology presented by Zavadskas and Turskis (2011).

The survey took place on November 11-23, 2020. The prepared questionnaire was sent by e-mail. To ensure the confidentiality of personal data, surveys are conducted anonymously.

To check the factors, risks and challenges determining the development of the sharing economy in the tourism sector discussed in the scientific literature, it is vital to analyze sharing economy-based business models and examine how experts evaluate sharing economy-based businesses. Hypotheses raised to assess the results of the peer review: 


\section{JOURNAL OF TOURISM AND SERVICES}

Issue 12, volume 22, ISSN 1804-5650 (Online)

www.jots.cz

- $H_{1}-$ Business models based on the sharing economy in the tourism sector are superior to traditional business models;

- $H_{2}$ - The sharing economy in the tourism sector is insufficiently regulated.

- $H_{3}-$ Traditional business in the tourism sector is affected by the development of sharing economy-based models.

- $H_{4}$ - The most important drivers of a sharing economy are economical.

Methodology for calculating the consistency of expert opinions. After the expert group $m$ has evaluated the analyzed indicators, the evaluations are first written in points according to the table below (Table 2).

Table 2. The expert's group's assessment

\begin{tabular}{|l|l|l|l|l|l|}
\hline \multirow{2}{*}{$\begin{array}{l}\text { Expert's } \\
\text { (respondent's) } \\
\text { code }\end{array}$} & $X_{1}$ & $X_{2}$ & $X_{3}$ & $\ldots$ & $X_{n}$ \\
\hline$E_{1}$ & $B_{11}$ & $B_{12}$ & $B_{13}$ & $\ldots$ & $B_{1 n}$ \\
\hline$E_{2}$ & $B_{21}$ & $B_{22}$ & $B_{23}$ & $\ldots$ & $B_{2 n}$ \\
\hline$\ldots$ & $\ldots$ & $\ldots$ & $\ldots$ & $\ldots$ & \\
\hline$E_{m}$ & $B_{m 1}$ & $B_{m 2}$ & $B_{m 3}$ & $\ldots$ & $B_{m n}$ \\
\hline
\end{tabular}

Source: Zavadskas \& Turskis, 2011

Next, all Bij scores are converted to ranks Rij, when the most important indicator is given a rank equal to one, the last most important indicator is ranked $\mathrm{n}$, when $\mathrm{n}$ is the number of benchmarks. Scores $\mathrm{Bij}$ are replaced by ranks Rij using the formula:

$$
R_{i j}=(n+1)-B_{i j}
$$

where $B_{i j}$ is the importance rating (score) assigned to the $\mathrm{i}$-th criterion of the $\mathrm{j}$-th expert, $\mathrm{m}$ number of experts (respondents), $\mathrm{n}$ - number of evaluated criteria (elements).

Next, the formula below is used to calculate each criterion $(i=1,2, \ldots, n)$ the sum of all the ranks assigned by the experts $R_{i}$ :

$$
R_{i}=\sum_{\mathrm{j}=1}^{\mathrm{m}}\left(6-\mathrm{B}_{\mathrm{ij}}\right)=\mathrm{m} * 6-\sum_{\mathrm{j}=1}^{\mathrm{m}} \mathrm{B}_{\mathrm{ij}}
$$

where $B_{i j}$ is the importance estimate (score) for the $\mathrm{i}$ - th criterion of the $\mathrm{j}$ - th expert, $\mathrm{m}$ - the number of experts (respondents. The average rank $\overline{R_{i}}$ of each criterion is also as:

$$
\overline{R_{i}}=\sum_{j=1}^{m} \frac{R i j}{m}
$$

where Rij is given to criterion $\mathrm{i}$ by the expert $\mathrm{j}, \mathrm{m}$ is the number of experts. Next, the difference between the sum of Rij and the constant is calculated for each element under consideration. The constant difference is calculated:

$$
\sum_{j=1}^{m} R_{i j}-\frac{m(n+1)}{2}
$$




\section{JOURNAL OF TOURISM AND SERVICES}

Issue 12, volume 22, ISSN 1804-5650 (Online)

www.jots.cz

where $\mathrm{Rij}$ - is the rank assigned to the expert $\mathrm{i}$ by the expert $\mathrm{j}, \mathrm{m}$ - number of experts, $\mathrm{n}$ - number of criteria. It is also necessary to calculate the sum $S$ of the squares of the constant difference, which can be calculated by the formula:

$$
S=\sum_{i=1}^{n}\left[\sum_{j=1}^{m} R_{i j}-\frac{1}{2} m(n+1]^{2}\right.
$$

where the value of S reflects the highest possible value when the opinions of the experts are similar and fully harmonized. When all values are found, the concordance coefficient is calculated according to the formula:

$$
w=\frac{12 S}{m^{2}\left(n^{3}-n\right)-m \sum_{j=1}^{m} T_{j}}
$$

where, $\mathrm{W}$ - concordance coefficient, $\mathrm{S}$ - the sum of the middle rank squares, $\mathrm{m}$ - the number of experts, $\mathrm{n}$ - the number of criteria presented, $\mathrm{Tj}$ - the index of the associated ranks.

When the number of benchmarks (elements) is small $(3<\mathrm{n}<7)$, and the critical value of the distribution $x_{k r}^{2}$ is bigger, the lowest concordance coefficient $W_{\text {min }}$, is calculated in which it can be said that the opinions of the experts are in agreement.

$$
W_{\min }=\frac{x_{v, a}^{2}}{m(n-1)}
$$

where $x_{v, a}^{2}$ - Pearson's criterion, with the chosen degree of reliability, $\mathrm{m}$ - number of experts, $\mathrm{n}$ - number of criteria. he significance of the concordance coefficient, determined according to the $x^{2}$ Pearson criterion, is further evaluated. If the calculated value is greater than $x_{k r}^{2}$ value, it can be said that the expert assessments are consistent. $x^{2}$ value is calculated as follows:

$$
x^{2}=W * m *(n-1)=\frac{12 * S}{m * n *(n+1)-1 /(n-1) * \sum T_{j}}
$$

where, $\mathrm{W}$ - concordance coefficient, $\mathrm{S}$ - sum of middle rank squares, $\mathrm{m}$ - number of experts, $\mathrm{n}$ - number of presented criteria, $\mathrm{Tj}$ - indicator of linked ranks. The significance of the analyzed criteria (elements) is assessed by calculating the significance indicator $Q_{i}$, which is determined:

$$
\begin{aligned}
q_{n} & =\frac{R_{n}}{\sum_{i=n}^{n} \overline{R_{i}}} \\
Q_{n} & =\frac{1-q_{n}}{n-1}
\end{aligned}
$$

where $\mathrm{n}$ - number of criteria, $\overline{R_{i}}$ - the average rank of criterion $\mathrm{i}$.

The significance indicator $Q_{i}$ shows the hierarchical order of importance of the analyzed indicators, and shows how many times one indicator is more important than another.

\section{Results and Discussion}

The expert evaluation's first questions reveal the available experience of experts in the field of tourism, the education acquired, the size of the company in which they work. According to the survey, we can say that most experts work in very small (37.5\%), small $(25 \%)$, and medium-sized enterprises 


\section{JOURNAL OF TOURISM AND SERVICES}

Issue 12, volume 22, ISSN 1804-5650 (Online)

www.jots.cz

(37.5\%). The majority of experts work in the field of accommodation $(75 \%)$ and have higher education (professional bachelor's or bachelor's degree - 62.5\%; master's degree or equivalent - $37.5 \%$ ).

In the second part of the expert assessment, the questions reveal the advantages and disadvantages of the sharing economy in the tourism sector from experts' perspectives.

Experts were first asked to assess the impact of sharing economy-based models on traditional businesses in the tourism sector. The calculated average ranks of the elements (Table 3) show that the area of information sharing economy in the tourism sector is more significant than the area of accommodation, transport and entertainment organization (information $>$ accommodation $>$ transport $>$ entertainment).

Table 3. Shared economy-based models influence on traditional businesses in the tourism sector by ranks

\begin{tabular}{|c|c|c|c|c|}
\hline \multirow{2}{*}{$\begin{array}{l}\text { Expert's (respondent's) } \\
\text { code }\end{array}$} & \multicolumn{4}{|c|}{ Criterion (indicator) marker } \\
\hline & Accommodation & Transport & Entertainment & Information \\
\hline $\begin{array}{l}\text { Sum of ranks } \\
\sum_{j=1}^{m} B_{i j}=B_{i}\end{array}$ & 12 & 30 & 32 & 11 \\
\hline$\overline{\mathrm{R}_{\mathrm{i}}}=\sum_{\mathrm{j}=1}^{\mathrm{Average} \mathrm{rank}} \frac{\mathrm{Rij}}{\mathrm{m}}$ & 1,5 & 3.8 & 4 & 1.38 \\
\hline $\begin{array}{l}\text { Difference } \\
\sum_{j=1}^{m} R_{i j}-\frac{m(n+1)}{2}\end{array}$ & -8 & 10 & 12 & -9 \\
\hline$\left[\sum_{j=1}^{m} \mathrm{R}_{\mathrm{ij}}-\frac{1}{2} \mathrm{~m}(\mathrm{n}+1)\right]^{2}$ & 64 & 100 & 144 & 81 \\
\hline$Q_{i}$ & 0,27 & 0,17 & 0,167 & 0,276 \\
\hline Hierarchy & 2 & 3 & 4 & 1 \\
\hline Compatibility & \multicolumn{4}{|c|}{$\begin{array}{l}\text { when } \alpha=0,05 \text {, then } x^{2}=10,4>x_{k r}^{2}=7,81473 \text {, } \\
\text { opinions are compatible }\end{array}$} \\
\hline
\end{tabular}

Source: own calucations

After calculations, we can state that the elements identified by the experts that have the most significant impact on the tourism sector (accommodation and information exchange) differ slightly and can be considered as equivalent. We note that the other elements (transport and entertainment) also differ slightly from each other.

The advantages of sharing economy-based businesses and traditional businesses in the tourism sector from experts' perspectives are further assessed.

After calculations (Table 4), we can say that the opinions of the experts are consistent. Analyzing the experts' assessments, the experts point out that the sharing economy in the tourism sector is superior to traditional business due to the consumer's ability to make new contacts and relationships with other community members ( 4.3 points) and the fast ordering process ( 4 points). It is noted that businesses based on the sharing economy are also considered to be superior in terms of the more attractive price offered to the consumer (3.74 points), the lower environmental damage ( 3.74 points), and the ratio of 
quality perceived by the consumer (3.5 points). So the hypothesis $\mathrm{H} 1$ is accepted - business models based on the sharing economy are superior to traditional business models.

Table 4. Comparison of sharing economy and traditional business in the tourism sector, from the point of view of experts

\begin{tabular}{|c|c|c|c|c|c|c|c|c|}
\hline \multirow{2}{*}{$\begin{array}{l}\text { Expert's } \\
\text { (respondent's) } \\
\text { code }\end{array}$} & \multicolumn{8}{|c|}{ Criterion (indicator) marker } \\
\hline & Speed & Price & Individuality & Communality & Quality & Reliability & Stock & Accessibility \\
\hline $\begin{array}{c}\text { Sum of Estimates } \\
\sum_{\mathrm{j}=1}^{m} B_{i j}=B_{i}\end{array}$ & 32 & 30 & 30 & 35 & 28 & 28 & 30 & 33 \\
\hline $\begin{array}{l}\text { Average estimate } \\
\overline{B_{i}}=\sum_{j=1}^{m} \frac{B i j}{m}\end{array}$ & 4 & 3,74 & 3,75 & 4,3 & 3,5 & 3,5 & 3,75 & 4,13 \\
\hline Hierarchy & 3 & $4-5$ & $3-4$ & 3 & 6 & 6 & $4-5$ & 1 \\
\hline Compatibility & \multicolumn{8}{|c|}{ when $\alpha=0,05$, then $x^{2}=19,37>x_{k r}^{2}=14,0671$, opinions are compatible } \\
\hline
\end{tabular}

Another question is to identify how businesses based on the sharing economy are assessed from a legal-economic point of view. The experts were asked to rate the statements on a 5-point scale, with 1 point indicating total disagreement with the statement and 5 points indicating complete agreement. The economic-legal assessment of the sharing economy of the interviewed expert group is presented in Table 5.

Table 5. Evaluation of sharing economy-based models and traditional business regulation

\begin{tabular}{|c|c|c|c|c|}
\hline \multirow{2}{*}{$\begin{array}{l}\text { Expert's (respondent's) } \\
\text { code }\end{array}$} & \multicolumn{4}{|c|}{ Criterion (indicator) marker } \\
\hline & Equally & $\begin{array}{l}\text { Insufficiently } \\
\text { regulated }\end{array}$ & Threat & $\begin{array}{l}\text { Opportunity to } \\
\text { cooperate }\end{array}$ \\
\hline $\begin{array}{l}\text { Sum of Estimates } \\
\sum_{j=1}^{m} B_{i j}=B_{i}\end{array}$ & 32 & 28 & 21 & 31 \\
\hline $\begin{array}{l}\text { Average estimate } \\
\overline{B_{i}}=\sum_{j=1}^{m} \frac{B i j}{m}\end{array}$ & 4 & 3,5 & 2,63 & 3,89 \\
\hline $\begin{array}{l}\text { Sum of ranks } \\
\sum_{j=1}^{m} B_{i j}=B_{i}\end{array}$ & 16 & 20 & 27 & 17 \\
\hline $\begin{array}{l}\text { Average rank } \\
\overline{\mathrm{R}_{\mathrm{i}}}\end{array}=\sum_{\mathrm{j}=1}^{\mathrm{m}} \frac{\mathrm{Rij}}{\mathrm{m}}$ & 2 & 2,5 & 3,38 & 2,16 \\
\hline Difference & -4 & 0 & 7 & -3 \\
\hline
\end{tabular}




\begin{tabular}{|l|l|l|l|l|}
\hline$\sum_{\mathrm{j}=1}^{\mathrm{m}} \mathrm{R}_{\mathrm{ij}}-\frac{\mathrm{m}(\mathrm{n}+1)}{2}$ & & & & \\
\hline $\begin{array}{l}\text { Square of diferrence } \\
{\left[\sum_{\mathrm{j}=1}^{\mathrm{m}} \mathrm{R}_{\mathrm{ij}}-\frac{1}{2} \mathrm{~m}(\mathrm{n}+1)\right]^{2}}\end{array}$ & 16 & 0 & 49 & 9 \\
\hline $\mathrm{Q}$ & 0,25 & 0,23 & 0.19 & 0,24 \\
\hline Hierarchy & 1 & 3 & 4 & 2 \\
\hline Compatibility & $\begin{array}{l}\text { when } \alpha=0,05, \text { then } \mathrm{x}^{2}=7,77<\mathrm{x}_{\mathrm{kr}}^{2}=7,81473, \\
\text { opinions are not compatible }\end{array}$ \\
\hline
\end{tabular}

Source: own calculations

After checking the consistency of the opinions with the coefficients of reliability and concordance, we can say that the experts' opinions are inconsistent. Using the ranking method, we can say that many experts point out that the sharing economy and traditional business must be regulated equally, so $\mathrm{H}_{2}$ is refused, - most experts do not believe that businesses based on the sharing economy are under-regulated.

Another question was asked to determine the impact of the sharing economy on traditional businesses in the tourism sector. Below is a diagram (Figure 6) showing how experts assess the sharing economy's impact on traditional business models in the tourism sector according to the criteria presented.

Figure 6. Assessing the impact of the sharing economy on traditional businesses in the tourism sector

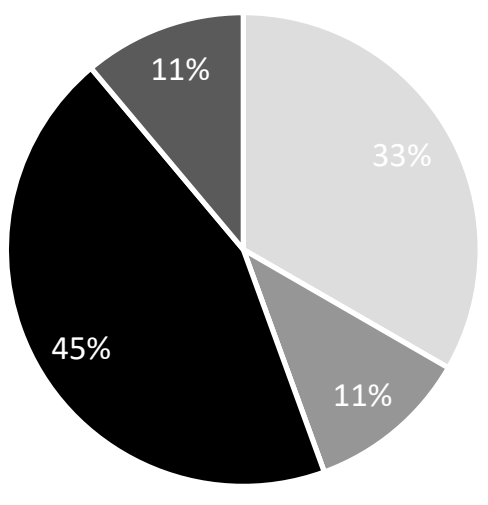

Demand has fallen

- Decreased turnover

- The need for workes has decreased

- Did nor affect

- Other

Source: Authors own conception

Some experts point out that the sharing economy's development has contributed to the reduced demand for traditional services companies in the tourism sector - 33 percent $(\mathrm{N}=3)$; reduced demand for staff; turnover - 11 percent $(\mathrm{N}=1)$; forming a lower demand for workers - 11 percent $(\mathrm{N}=1)$. Although most experts point out that traditional businesses are affected by sharing economy-based businesses, some experts point out that the sharing economy has not affected the traditional tourism sector $(\mathrm{N}=4 ; 45$ percent). In summary, experts disagree on the sharing economy's impact on traditional businesses in the tourism sector. Expert judgment is provided regardless of the sector represented by the respondents. Thus, $\mathrm{H}_{3}$ can not be considered reasonable - traditional business in the tourism sector is not affected by the development of sharing economy - based models. 


\section{JOURNAL OF TOURISM AND SERVICES}

Issue 12, volume 22, ISSN 1804-5650 (Online)

www.jots.cz

The factors promoting the development of the sharing economy in the tourism sector are analyzed below from experts' point of view. The assessment of the issue analyzed by the expert group is presented in the table below (Table 6).

Table 6. Factors driving the development of the sharing economy

\begin{tabular}{|c|c|c|c|c|c|c|}
\hline \multirow{2}{*}{$\begin{array}{l}\text { Expert's } \\
\text { (respondent's) } \\
\text { code }\end{array}$} & \multicolumn{6}{|c|}{ Criterion (indicator) marker } \\
\hline & $\begin{array}{l}\text { Improving the } \\
\text { quality of life }\end{array}$ & $\begin{array}{l}\text { Growing } \\
\text { aggregated } \\
\text { demand }\end{array}$ & $\begin{array}{l}\text { Climate } \\
\text { change }\end{array}$ & Urbanization & Tehcnological & Recession \\
\hline $\begin{array}{c}\text { Sum of Estimates } \\
\sum_{\mathrm{j}=1}^{\mathrm{m}} \mathrm{B}_{\mathrm{ij}}=\mathrm{B}_{\mathrm{i}}\end{array}$ & 32 & 31 & 37 & 37 & 36 & 37 \\
\hline $\begin{array}{l}\text { Sum of Ranks } \\
\qquad \sum_{j=1}^{m} B_{i j}=B_{i}\end{array}$ & 16 & 17 & 11 & 11 & 12 & 11 \\
\hline $\begin{array}{l}\text { Average rank } \\
\overline{\mathrm{R}_{\mathrm{i}}}=\sum_{\mathrm{m}=1}^{\mathrm{Rij}} \frac{\bar{m}}{}\end{array}$ & 2 & 2,13 & 1,38 & 1,38 & 1,5 & 1,38 \\
\hline $\begin{array}{l}\text { Difference } \\
\sum_{j=1}^{m} R_{i j} \\
-\frac{m(n+1)}{2}\end{array}$ & 1 & -11 & -17 & -17 & -16 & -17 \\
\hline $\begin{array}{l}\text { Square of } \\
\text { difference } \\
{\left[\sum_{\mathrm{j}=1}^{\mathrm{m}} \mathrm{R}_{\mathrm{ij}}-\right.} \\
\left.\frac{1}{2} \mathrm{~m}(\mathrm{n}+1)\right]^{2}\end{array}$ & 1 & 121 & 289 & 289 & 256 & 289 \\
\hline $\mathrm{Q}$ & 0,15 & 0,15 & 0,17 & 0,17 & 0,16 & 0,17 \\
\hline Hierarchy & $1-2$ & $1-2$ & $4-5-6$ & $4-5-6$ & 3 & $4-5-6$ \\
\hline Compatibility & when $\alpha=0,0$ & then $x^{2}=1$ & $59>x_{k}^{2}$ & 1,0705 , opini & Is are compatibl & \\
\hline
\end{tabular}

After analyzing the data, we can say that the opinions of the experts are consistent. Experts name the most important drivers of the sharing economy - economic (improving quality of life $\mathrm{Q}=0.15$ and growing aggregate demand $Q=0.15$ )- hypothesis $H_{4}$ is accepted. Experts also point out that the sharing economy's development is strongly influenced by technological factors $\mathrm{Q}=0.16$ (mobile apps, social networks, the spread of the internet and mobile devices).

After analyzing the development of sharing economy-based models in Lithuania's tourism sector and the reasons that encourage consumers to use sharing economy-based platforms, we can say that the term "sharing economy", especially in the context of tourism, will remain at the center of academic discourse. The sharing economy in the tourism sector is an excellent way for travelers to interact with locals and gain a real, authentic experience. However, the sharing economy in the tourism sector, on the other hand, is an under-regulated business model characterized by tax evasion, labor rights violations and a lack of consumer protection laws.

Another area of discussion is the importance of traditional business in the tourism sector. Given the study results, the question arises as to whether the traditional business model will remain as important 


\section{JOURNAL OF TOURISM AND SERVICES}

Issue 12, volume 22, ISSN 1804-5650 (Online)

www.jots.cz

in the tourism sector as the level of urbanization increases and conditions for travelers of all ages to learn to use mobile apps and other smart platforms. As the number of potential customers in traditional businesses decreases, so do the prices of traditional services (due to the maintenance of the developed tourism infrastructure, staff, and other necessary costs), which are identified as a critical factor in choosing a tourism service provider.

Although this study's sample size is sufficient for the tourism sector, qualitative data on the development of the sharing economy in the tourism sector alone do not provide sufficient evidence. In the future, it will be useful to supplement the study with quantitative data.

\section{Conclusion}

The sharing economy has become an essential part of the global economy. Based on the sharing economy principles, the tourism sector includes accommodation, transport, entertainment and the search for tourist information.

The development of sharing economy-based businesses in the tourism sector creates new tourism experiences and transforms values, motives, reasons, and traveling ways. Business based on the sharing economy principles, operating in the tourism sector, makes a significant contribution to economic growth, social well-being and solving ecological problems. Although sharing economy-based models has many positive consequences for the tourism sector (e.g., lower prices, promotion of community spirit), shortcomings have also been identified. The authors of the study found that businesses based on the sharing economy contribute to some social problems. Problems of tax collection, rebound effect, disruption of the local community, security concerns, and unclearly regulated duties and responsibilities were also examined. The negative impact of the sharing economy poses problems for the successful development of the tourism sector's sharing economy. However, despite the negative impact of sharing economy-based business models, the studied business model is considered the most advantageous, highest value-added business model in the tourism sector. The main areas of the tourism sector where the sharing economy is expanding are accommodation, transportation and information sharing. Once the incentives for the development of the sharing economy in the tourism sector have been identified and assessed, we can say that the popularity of sharing economy-based businesses in the tourism sector will continue to grow. Consumers and business partners have been found to have the most significant positive impact on the tourism sector's sharing economy. It has been analyzed that with the rapid and widespread entry of the sharing economy into the tourism sector, traditional businesses and public authorities tend to hamper the development of sharing economy-based business models. The example of developing a sharing economy proves that all stakeholders must be prepared for change, take into account trends, change needs, and look for opportunities to meet consumer needs more quickly and accept changes in the market.

Although the study was conducted in the Lithuanian tourism sector, we can assume that the study data can be unified and applied to analyze similar markets in other countries.

\section{References}

1. Augustinaitis, A. (2009). Lietuvos e. valdžios gaires: ateities ižvalgu tyrimas (kolektyvinè monografija). Vilnius: Mykolo Romerio universiteto leidybos centas.

1. Bilan, Y., Brychko, M., Buriak, A., \& Vasilyeva, T. (2019). Financial, business and trust cycles: The issues of synchronization. Zbornik Radova Ekonomskog Fakultet Au Rijeci,37(1), 113-138. https://doi.org/10.18045/zbefri.2019.1.113

2. Bilan, Y., Rubanov, P., Vasylieva, T., \& Lyeonov, S. (2019). The influence of industry 4.0 on 


\section{JOURNAL OF TOURISM AND SERVICES}

Issue 12, volume 22, ISSN 1804-5650 (Online)

www.jots.cz

financial services: Determinants of alternative finance development. [Wpływ przemysłu 4.0 na usługi finansowe: determinanty rozwoju alternatywnych finansów] Polish Journal of Management Studies, 19(1), 70-93. doi:10.17512/pjms.2019.19.1.06

3. Bosque, D. (2018). Spain taxi strike against Uber to continue. Prieiga per interneta: https://www.thelocal.es/20180731/spain-taxi-strike-against-uber-to-continue

4. Botsman, R., Rogers, R. (2010). Beyond Zipcar: Collaborative consumption. Harvard Business Review, 88(10), (30 - 32).

5. Chakraborty, A., Hannak, A., Biega, A., J. \& Gummadi, K., P. (2017). Fair sharing for sharing economy platforms. Proceedings of FATREC Workshop on Responsible Recommendation at RecSys (1 4). DOI: 10.18122/B2BX2S

6. Chen, T., D. \& Kockelman, K., M. (2016). Carsharing's life-cycle impacts on energy use and greenhouse gas emissions. Transportation Research Part D Transport and Environment $(276$ - 284). https://doi.org/10.1016/j.trd.2016.05.012

7. Committee of the Regions (2017). URBAN Assesment, The Sharing Economy. Official Journal of the European Union (2 - 5). Retrieved from: https://eur-lex.europa.eu/legalcontent/LT/TXT/PDF/?uri=CELEX:52016IR4163\&from=EN.

8. Consoy, M., S. (2018). Sharing in usequal spaces. Bonston College. (1 - 162). Retrieved from http://hdl.handle.net/2345/bc-ir:108139

9. Curtis, S. \& Lehner, M. (2019). Defining the sharing economy for sustainability. Sustainability 11 (3): 567. (1 - 27). Doi: 10.3390/su11030567

10. Dkhili, H. (2018). Environmental performance and institutions quality: evidence from developed and developing countries. Marketing and Management of Innovations, 3, 333-244. http://doi.org/10.21272/mmi.2018.3-30

11. Domi, S., Keco, R., Capelleras, J.-L., \& Mehmeti, G. (2019). Effects of innovativeness and innovation behavior on tourism SMEs performance: The case of Albania. Economics and Sociology, 12(3), 67-85. doi:10.14254/2071-789X.2019/12-3/5

12. Ferrer, R. (2018). The sharing economy and tourism. Dossier, MR07, (34-35). Retrieved from: https://www.caixabankresearch.com/en/sector-analysis/tourism/sharing-economy-andtourism?fbclid=IwAR1NQJB34JtrDyGToJursNuaAsx4TOu1phoPp9mzeD115fB01EQmabA $\mathrm{N} 72 \mathrm{k}$

13. Hong, J. (2018). Rise of the sharing economy and the future of travel and tourism industry. Journal of Hotel \& Business Management.(1-11). DOI: 10.4172 / 2169-0286.1000180

14. Ibragimov, Z., Lyeonov, S., \& Pimonenko, T. (2019). Green investing for SDGS : EU experience for developing countries. Economic and Social Development: Book of Proceedings, 37 th International Scientific Conference on Economic and Social Development "Socio Economic Problems of Sustainable Development". P. 868-877. Retrieved from https://www.econbiz.de/Record/ economic-social-development-37th-international-scientific-conference-economic-socialdevelopment-socio-economic-problems-sustainable-development-book/10011972194

15. Yang, Z., Ma, L. \& Zhang, Z. (2018). Sharing Economy: A state og the art survey. Advances in Social Science, Education and Humanities Research, 275 (425 - 230). https://doi.org/10.2991/iceiss18.2018.103

16. Ivanova, M. (2015). Sharing economy: Bulgarian tourism industry perspective. Proceedings of International Conference "Tourism in the age of transformation ", (479-488). Retrieved from https://www.academia.edu/31807587/SHARING_ECONOMY_BULGARIAN_TOURISM_ INDUSTRY_PERSPECTIVE.

17. Ključnikov, A., Popesko, B., \& Kloudová, J. (2019). Economics of the international ridesharing services-a trap for amateurs. Entrepreneurship and Sustainability Issues, 6(3), 1172-1181. https://doi.org/10.9770/jesi.2019.6.3(8) 


\section{JOURNAL OF TOURISM AND SERVICES}

Issue 12, volume 22, ISSN 1804-5650 (Online)

www.jots.cz

18. Ključnikov, A., Krajč́k, V., Vincúrová, Z. (2018). International Sharing Economy: the Case of AirBnB in the Czech Republic. Economics and Sociology, 11(2), 126-137. doi: 10.14254/2071789X.2018/11-2/9

19. Krajcik, V., Kljucnikov, A., \& Rihova, E. (2019). Innovative Sharing Economy's Business Models in Tourism: Case of Airbnb in Prague. Marketing and Management of Innovations, 2, 108-117. http://doi.org/10.21272/mmi.2019.2-10

20. Lombard, C. (2015). Pros and Cons of Sharing Economy. Retrieved from http:// visionlaunch.com/pros-and-cons-of-sharing-economy/

21. Lougher, G. \& Kalmanowicz, S. (2016). EU Competition Law in the Sharing Economy. Journal of European Competition Law \& Practice, $(87$ - 102). https:/ / doi.org/10.1093/jeclap/lpv086

22. Mair, J. \& Reischauer, G. (2017). Capturing the dynamics of the sharing economy: Institutional research on the plural forms and practices of sharing economy organizations. Technological Forecasting and Social Change, 125, (11-20). https://doi.org/10.1016/j.techfore.2017.05.023

23. Mair, J. \& Reischauer, G. (2017). Capturing the dynamics of the sharing economy: Institutional research on the plural forms and practices of sharing economy organizations. Technological Forecasting and Social Change, 125, (11-20). https://doi.org/10.1016/j.techfore.2017.05.023

24. OECD (2016). Tourism trends and Policies. Retrieved from https://www.oecdilibrary.org/docserver/8f06cc90en.pdf?expires $=1606917450 \& \mathrm{id}=\mathrm{id} \&$ accname $=$ guest\&checksu $\mathrm{m}=\mathrm{A} 61 \mathrm{D} 1 \mathrm{CCBE} 650 \mathrm{D} 084 \mathrm{DDF} 53 \mathrm{C19895B204A}$

25. Onete, C., B., Plesea, D. \& Budz, S. (2018). Sharing economy: Challenges and Opportunities in tourism. Amfiteatru Economic, 20 (Special No. 12) (998-1015). DOI: 10.24818 / EA / 2018 / S12 / 9

26. Parente, R., C., Gelelaite J., G., \& Rong, K. (2018). The sharing economy globalization phenomenon: a research agenda. Journal of International Management (52 - 64). doi: 10.1016 / j.intman.2017.10.001

27. Pjerotic, L. (2017). Stakeholder cooperation in implementation of the sustainable development concept: Montenegrin tourist destinations. Journal of International Studies, 10(2), 148-157. doi:10.14254/2071-8330.2017/10-2/11

28. Popesko, B., Ključnikov, A., Hrabec, D., \& Dokulil, J. (2016). Predictability of business environment within budgeting process - is it connected with fluctuations of economy? Economics and Sociology, 9(2), 90-100. https://doi.org/10.14254/2071-789X.2016/9-2/6

29. Roblek, V., Štok M., Z. \& Meško, M. (2016). Complexity of a sharing economy for tourism and hospitality. Tourism \& Hospitality Industry. Congree Proceedings, (374-387). DOI: 10.13140 / RG.2.1.3000.2165

30. Schor, J. (2016). Debating the sharing economy. Journal of Self-Governance and Management Economics, 4(3), 7-22. doi: 10.22381 / JSME4320161

31. Schwab, K. (2018). Ketvirtoji pramonés revoliucija. Vilnius: Vaga, 208 p.

32. Silva, G. \& Silva R. (2020). Clarifying the Sharing Economy: Conceptualization, Typology, Antecedents, and Effects. Academy of Management Perspectives, 34(1). https://doi.org/10.5465/amp.2017.0010

33. Srovnalikova, P., Semionovaite, E., Baranskaitè, E. \& Labanauskaitè, D., (2020). Evalutation of the impact of sharing economy on hotel business. Journal of Tourism and Services, 20(11), 150-169. doi: $10.29036 /$ jots.v11i20.145.

34. Šiuškaite, D., Pilinkienè, V. \& Žvirdauskas D. (2019). The Conceptualization of the Sharing Economy as a Business Model. Inzinerine Ekonomika - Engineering Economics 30(3), (373 - 381). doi: 10.5755 / j01.ee.30.3.21253

35. Teubner, T. \& Flath, C., M. (2019). Privacy in the Sharing Economy. Journal of the Association for Information Systems 20(3). DOI: 10.17705/1jais.00534 


\section{JOURNAL OF TOURISM AND SERVICES}

Issue 12, volume 22, ISSN 1804-5650 (Online)

www.jots.cz

36. The World Bank Group, 2018. Tourism and the Sharing economy: policy and potential of sustainable peerto - peer accommodation. Retrieved from https://openknowledge.worldbank.org/bitstream/handle/10986/30452/130054-REVISEDTourism-and-the-Sharing-Economy-PDF.pdf?sequence $=1$ \&is Allowed $=\mathrm{y}$

37. Tussyadiah, I.\& Pesonen, J., A. (2015). Impact of peer - to - peer accommodation use of travel patterns. Journal of travel research. doi: 10.1177 / 0047287515608505

38. Uddin, S., Popesko, B., Papadaki, Š., \& Wagner, J. (2021). Performance measurement in a transitional economy: Unfolding a case of KPIs. Accounting, Auditing and Accountability Journal, 34(2), 370-396. https://doi.org/10.1108/AAAJ-11-2019-4231

39. Vall, S. \& Schor, B., J. (2020). What do platforms do? Understanding the gig economy. Annual review of sociology (273 - 294$)$. Retrieved from https://www.annualreviews.org/doi/full/10.1146/annurev-soc-121919-054857

40. Vasilieva, T., Lieonov, S., Makarenko, I. \& Sirkovska, N. (2017) Sustainability information disclosure as an instrument of marketing communication with stakeholders: markets, social and economic aspects. Marketing and Management of Innovations, 4, 350-357. DOI: 10.21272/mmi.2017.4-31

41. Vaskelainen, T. \& Piscicelli, L. (2018). Online and offline communities in the sharing economy. Sustainability (1 - 18). DOI: 10.3390/su10082927

42. World travel \& tourism council [WTTC], (2019). Economic impact reports. Retrieved from https://wttc.org/Research/Economic-Impact

43. Xi ,Y., Leung, L. \& Xue, H. W. (2019). Framing the sharing economy: Toward a sustainable ecosystem. Tourism Management, 71. (44 - 53). https://doi.org/10.1016/j.tourman.2018.09.021

44. Zavadskas, E. K. \& Turskis, Z. (2011). Multiple criteria decision making (MCDM) methods in economics: An overview. Technological and Economic Development of Economy 17(2), 397-427. https://doi.org/10.3846/20294913.2011.593291

\section{Brief description of Authors:}

\section{Prof. Ing. Dr. Valentinas Navickas.}

ORCID ID: https://orcid.org/0000-0002-7210-4410

Doctor of social sciences (economics), professor at Kaunas University of Technology (Lithuania), School of Economics and Business. E-mail: valna@ktu.lt. Author of more than 360 scientific publications (including monographs published in the Czech Republic in 2013 and Slovak Republic in 2016, 2018) and scientific articles published in Lithuania and abroad. Prepared 7 doctors of social (economics) science; now, he is a research adviser of 3 persons maintaining a doctor's thesis of social (economics) science. Fields of scientific interest: development economics, competitiveness, economic growth, sharing economy, tourism economics.

\section{Mgr. Ieva Petrokè.}

School of Economics and Business, Kaunas University of Technology, Lithuania, e-mail: ieva.petroke@gmail.com. Fields of scientific interest: economic growth, development economics, sharing economy, tourism economics.

ORCID ID: https://orcid.org/0000-0001-8937-1219

\section{Mgr. Vaida Bačiulienè.}




\section{JOURNAL OF TOURISM AND SERVICES}

Issue 12, volume 22, ISSN 1804-5650 (Online)

www.jots.cz

School of Economics and Business, Kaunas University of Technology, Lithuania, e-mail: vaida.baciuliene@gmail.com. Fields of scientific interest: economic growth, development economics, sharing economy, tourism economics.

ORCID ID: https://orcid.org/0000-0002-0558-432x

\section{Prof. Tetiana Vasylieva}

Doctor of Economics, Director of the Institute of Business, Economics and Management. Sumy State University, Ukraine. E-mail: tavasilyeva@fem.sumdu.edu.ua. Author of more than 400 scientific publications. Has prepared 15 doctors of economic sciences and 22 candidates. Deputy Chairman of the "Economics" Section of the Academic Council of the Ministry of Education and Science of Ukraine. Head of the ARMG Publishing Center. Honorary member of the board of the European Marketing and Management Association. Head of 50 scientific and educational international grant projects. Areas of research interests: digitalization and information security of the economy, development of the financial sector, social, economic and environmental relations in society.

ORCID ID: https://orcid.org/0000-0003-0635-7978

\section{Appendix}

Annex 1. Expert evaluation of applied sharing economy based models, expert survey questionnaire

\section{General information about the expert}

\subsection{Your work experience in the tourism sector:}

\begin{tabular}{|l|l|l|}
\hline 1 & Up to 3 years & $\square$ \\
\hline 2 & $3-5$ years & $\square$ \\
\hline 3 & $5-10$ years & $\square$ \\
\hline 4 & 10 and more years & $\square$ \\
\hline
\end{tabular}

\subsection{Size of your company (organization):}

\begin{tabular}{|l|l|l|}
\hline 1 & Micro enterprise $(1-9$ people) & $\square$ \\
\hline 2 & Small $(10-49$ people $)$ & $\square$ \\
\hline 3 & Average $(50-249$ people $)$ & $\square$ \\
\hline 4 & Large $(>250$ people $)$ & $\square$ \\
\hline
\end{tabular}

\subsection{You are working:}

\begin{tabular}{|l|l|l|}
\hline 1 & In the accommodation area & $\square$ \\
\hline 2 & In the field of travel organization & $\square$ \\
\hline 3. & Vehicle rental & $\square$ \\
\hline
\end{tabular}




\begin{tabular}{|l|l|l|}
\hline 4 & Entertainment organization & $\square$ \\
\hline 5 & Other (please specify) & $\square$ \\
\hline
\end{tabular}

\subsection{Your education:}

\begin{tabular}{|l|l|c|}
\hline 1 & Major/ Incoplete secondary & $\square$ \\
\hline 2 & Secondary/ Special secondary & $\square$ \\
\hline 3 & Professional & $\square$ \\
\hline 4 & Incomplete higher & $\square$ \\
\hline 5 & Higher (professional bachelor / bachelor's qualification degree) & $\square$ \\
\hline 6 & Higher (master's degree or equivalent) & $\square$ \\
\hline 7 & Higher (doctoral degree) & $\square$ \\
\hline 8 & Other (please specify) & $\square$ \\
\hline
\end{tabular}

\section{Experts' evaluation}

2.1. From 1 to 5, assess the impact of sharing economy-based models on traditional businesses in the tourism sector, according to the following areas:

(5 - large; 4 - partially large; 3 - neither large nor small; 2 - partially small; 1 - small).

\begin{tabular}{|l|l|l|l|l|l|l|}
\hline 1 & Accommodation platforms (eg.. "Airbnb") & $1 \square$ & $2 \square$ & $3 \square$ & $4 \square$ & $5 \square$ \\
\hline 2 & Transport platforms (eg. "CityBee") & $1 \square$ & $2 \square$ & $3 \square$ & $4 \square$ & $5 \square$ \\
\hline 3 & $\begin{array}{l}\text { Entertainment at the destination booking platform (eg. } \\
\text { "Triple") }\end{array}$ & $1 \square$ & $2 \square$ & $3 \square$ & $4 \square$ & $5 \square$ \\
\hline 4 & Informations sharing platforms (eg. "Tripadvisor") & $1 \square$ & $2 \square$ & $3 \square$ & $4 \square$ & $5 \square$ \\
\hline
\end{tabular}

2.2. From one to five, evaluate the following aspects, evaluating the advantage between traditional business and sharing economy-based businesses in the tourism sector:

(5 - sharing economy-based businesses are the best; 4 - more sharing economy-based businesses; 3 equal; 2 - better traditional business; 1 - best traditional business).

\begin{tabular}{|l|l|l|l|l|l|l|}
\hline 1 & Speed of service provision & $1 \square$ & $2 \square$ & $3 \square$ & $4 \square$ & $5 \square$ \\
\hline 2 & Lower cost of services & $1 \square$ & $2 \square$ & $3 \square$ & $4 \square$ & $5 \square$ \\
\hline 3 & Meeting individual needs & $1 \square$ & $2 \square$ & $3 \square$ & $4 \square$ & $5 \square$ \\
\hline 4 & Promoting community & $1 \square$ & $2 \square$ & $3 \square$ & $4 \square$ & $5 \square$ \\
\hline 5 & Better wuality of service & $1 \square$ & $2 \square$ & $3 \square$ & $4 \square$ & $5 \square$ \\
\hline 6 & Reliability & $1 \square$ & $2 \square$ & $3 \square$ & $4 \square$ & $5 \square$ \\
\hline 7 & Wider choce of goods/ services & $1 \square$ & $2 \square$ & $3 \square$ & $4 \square$ & $5 \square$ \\
\hline 8 & Availability of services & $1 \square$ & $2 \square$ & $3 \square$ & $4 \square$ & $5 \square$ \\
\hline
\end{tabular}




\subsection{Evaluate the statements below:}

(5- strongly agree; 4- partially agree; 3-neither agree nor disagree; 2- partially disagree; 1 - strongly disagree).

\begin{tabular}{|l|l|l|l|l|l|l|}
\hline 1 & $\begin{array}{l}\text { The sharing economy and traditional businesses in the } \\
\text { tourism sector should be regulated in the same way }\end{array}$ & $1 \square$ & $2 \square$ & $3 \square$ & $4 \square$ & $5 \square$ \\
\hline 2 & $\begin{array}{l}\text { The development of a sharing economy in the } \\
\text { tourism sector should be more tightly regulated }\end{array}$ & $1 \square$ & $2 \square$ & $3 \square$ & $4 \square$ & $5 \square$ \\
\hline 3 & $\begin{array}{l}\text { The development of a sharing economy in the } \\
\text { tourism sector is a threat to traditional businesses }\end{array}$ & $1 \square$ & $2 \square$ & $3 \square$ & $4 \square$ & $5 \square$ \\
\hline 4 & $\begin{array}{l}\text { Traditional businesses should work with sharing } \\
\text { economy-based businesses in the tourism sector to } \\
\text { stay competitive }\end{array}$ & $1 \square$ & $2 \square$ & $3 \square$ & $4 \square$ & $5 \square$ \\
\hline
\end{tabular}

2.4. How do you think the sharing economy has affected traditional business models in the tourism sector?

\begin{tabular}{|l|l|r|}
\hline 1 & Decreased demand & $\square$ \\
\hline 2 & Decreased turnover & $\square$ \\
\hline 3 & Decreased need for staff & $\square$ \\
\hline 4 & Not affected & $\square$ \\
\hline 5 & Other (please specify) & $\square$ \\
\hline
\end{tabular}

\subsection{What impact does each of these factors have on the growth of the sharing economy?}

(5- large; 4- not very large; 3-neither large nor small; 2- partially small; 1- small)

\begin{tabular}{|l|l|l|l|l|l|l|}
\hline 1 & Improving the quality of life & $1 \square$ & $2 \square$ & $3 \square$ & $4 \square$ & $5 \square$ \\
\hline 2 & Climate change & $1 \square$ & $2 \square$ & $3 \square$ & $4 \square$ & $5 \square$ \\
\hline 3 & $\begin{array}{l}\text { Growing aggregate demand for services in the tourism } \\
\text { sector }\end{array}$ & $1 \square$ & $2 \square$ & $3 \square$ & $4 \square$ & $5 \square$ \\
\hline 4 & Urbanization & $1 \square$ & $2 \square$ & $3 \square$ & $4 \square$ & $5 \square$ \\
\hline 5 & Technological development & $1 \square$ & $2 \square$ & $3 \square$ & $4 \square$ & $5 \square$ \\
\hline 6 & Recession & $1 \square$ & $2 \square$ & $3 \square$ & $4 \square$ & $5 \square$ \\
\hline
\end{tabular}

